\title{
Studies On Some Acid Divalent-Metal Nitrilotriacetate Complexes.
}

\author{
E.R. Souaya, W.G. Hanna*, E.H. Ismail and N.E. Milad \\ Department of Chemistry, Faculty of Science, Ain Shams University, Cairo, Egypt, 11566 \\ * Author to whom correspondence should be addressed; E-mail: wageih@hotmail.com.
}

Received: 7 Jul 2000; in revised form 23 Aug 2000 / Accepted: 20 Sep 2000 / Published: 31 Oct 2000

\begin{abstract}
IR and ${ }^{1} \mathrm{H}-\mathrm{NMR}$ studies on nitrilotriacetic acid $\left(\mathrm{H}_{3} \mathrm{NTA}\right)$ suggest that the acid exists in the zwitterion form, which allows the existence of intermolecular hydrogen bonding. A tetrahedral structure is established for eleven (1:1) anhydrous acid-metal (II) nitrilotriacetates complexes. The ten $\mathrm{Dq}$ values for the colored complexes were determined spectrophotometrically. The $\mathrm{pK}_{\mathrm{a}}$ values for the eleven acid metal complexes $\left.[\mathrm{M}(\mathrm{HNTA})] .\left(\mathrm{OH}_{2}\right)_{3}\right]$ were determined and compared with the corresponding $\mathrm{pK}_{\mathrm{a}}$ values of the $\left[\mathrm{M}\left(\mathrm{OH}_{2}\right)_{\mathrm{n}}\right]^{+2}$ ions and also with the $\log \beta_{1}$ values of the corresponding $[\mathrm{M}(\mathrm{NTA})]^{-}$ complexes. X-ray diffraction studies on the ligand and on eight of these complexes are described.
\end{abstract}

Keywords: nitrilotriacetic acid, nitrilotriacetates complexes, $\mathrm{pK}_{\mathrm{a}}$ values, $\mathrm{X}$-ray diffraction

\section{Introduction}

A high content of chemical pollutants in soils and water may adversely affect plant and animal growth and in turn human health. Contamination of soils with such pollutants could be due to the application of chemical fertilizers, sewage, sludge, herbicides, industrial activities, etc. or irrigation with contaminated water. Although a literature survey reveals that nitrilotriacetic acid $\left(\mathrm{H}_{3} \mathrm{NTA}\right)$, and its metal complexes are extensively used in medical, biological and environmental studies, very little work has been carried out on $\left(\mathrm{H}_{3} \mathrm{NTA}\right)$ and its metal complexes from a purely chemical point of view. 
The aim of the present investigation is to study such properties in order to understand the way in which such materials are effective.

Nitrilotriacetic acid $\left(\mathrm{H}_{3} \mathrm{NTA}\right)$ is perhaps historically the most important of the complexones other than $\mathrm{H}_{4}$ EDTA. We were able to find over 100 publications dealing with the use of $[\mathrm{NTA}]^{\mathrm{n}-}$ and its metal complexes in water and soil treatment as well as in biological and medical research. [NTA $]^{\mathrm{n}-}$ was also used in detergents to replace sodium tripolyphosphate [1.2]. Among other fields in which [NTA] ${ }^{\mathrm{n}-}$ or its metal chelates were used are dying and bleaching [3].

Rabenstien and Kula [4] observed that the rate of ligand exchange in $\mathrm{Cd}$, Zn and [Pb: (NTA)] when $\left[\mathrm{H}_{2} \mathrm{NTA}\right]^{-}$is in the mono-protonated from is significantly less than the rate when $[\mathrm{NTA}]^{3-}$ is in the totally ionized form. Maguire [5] explained the slower rate of [HNTA $]^{2-}$ reaction with copper ion than $[\mathrm{NTA}]^{3-}$ to be due to the fact that a rate limiting proton transfer step from nitrogen in $[\mathrm{HNTA}]^{2-}$ must occur before complex formation takes place.

Despite the immense number of publications of the use of $\mathrm{H}_{3} \mathrm{NTA}$ and its chelates in different applied, medical, biological and industrial fields, we were able to locate only one publication [6] on the preparation and identification of solid $\mathrm{HM}^{\mathrm{II}} \mathrm{NTA}$ complexes. The importance of the acid nitrilotriacetates stems from the various uses of NTA complexes in acid media. Although $\mathrm{H}_{3} \mathrm{NTA}$ forms 1:1 and 1:2 [metal:(NTA)] complex [7], the present study will be concerned with the 1:1 complexes only.

\section{Results and discussion}

The infrared spectrum of nitrilotriacetic acid over the range $4000-200 \mathrm{~cm}^{-1}$ shows three interesting bands at 1434, 1733 and $3041 \mathrm{~cm}^{-1}$. The bands of interest in the IR spectrum of $\mathrm{H}_{2} \mathrm{KNTA}$ are those at 1440, 1720 and $3040 \mathrm{~cm}^{-1}$. The bands at 1730 and $3040 \mathrm{~cm}^{-1}$ do not appear in the IR spectrum of $\mathrm{K}_{3}$ NTA where there is a broad band at $1650-1600 \mathrm{~cm}^{-1}$ and another one at $1420 \mathrm{~cm}^{-1}$.

The fact that the band at $\sim 1430 \mathrm{~cm}^{-1}$ is present in the spectra of the three compounds and which was previously assigned to the symmetric stretching frequency of the COO- [9] suggests that $\mathrm{H}_{3} \mathrm{NTA}$ is present in the zwitterion form.

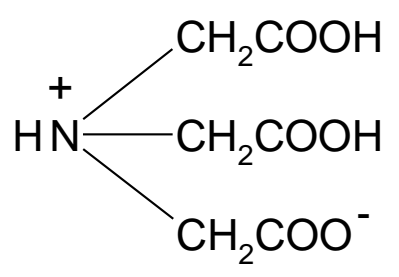

Again the presence of the band at $\sim 1730 \mathrm{~cm}^{-1}$ in the spectra of $\mathrm{H}_{3}$ NTA and $\mathrm{H}_{2} \mathrm{KNTA}$ justifies its previous assignment to the undissociated $-\mathrm{COOH}$ stretching vibration [10].

Finally the band at $\sim 3040 \mathrm{~cm}^{-1}$ which appears in the spectra of $\mathrm{H}_{3}$ NTA and $\mathrm{H}_{2} \mathrm{KNTA}$ is assigned to some sort of N-H stretching frequency. Comparing this band with that for gaseous ammonia (3335- 
$3337 \mathrm{~cm}^{-1}$ ) [10] and those for complexed ammonia in ammonio complexes (3250-3050 $\left.\mathrm{cm}^{-1}\right)$ [10], it may be argued that the N-H frequency is lowered via some sort of hydrogen bonding. Tajmir-Riahi [11] who assigned the broad band at $2700 \mathrm{~cm}^{-1}$ in some Schiff bases to an intramolecular hydrogen bonding (O-H...N) gave a similar argument. This band shifts to $3000 \mathrm{~cm}^{-1}$ in the spectra of Schiff base complexes as the hydrogen bond arrangement changes to $\left(\mathrm{O} \ldots \mathrm{HN}^{+}\right)$.

We sought to establish whether this hydrogen bonding in our ligand $\left(\mathrm{H}_{3} \mathrm{NTA}\right)$ is intramolecular or intermolecular by comparing the melting points of nitrilotriacetic acid $\left(246{ }^{\circ} \mathrm{C}\right)$ with that of citric acid $\left(152{ }^{\circ} \mathrm{C}\right)$ where the two acids are tricarboxylic and the molecular weights are almost the same (191 and 192 respectively). This large difference in the melting points suggests that the hydrogen bond in $\mathrm{H}_{3}$ NTA is intermolecular.

In order to gain more insight into the structure of $\mathrm{H}_{3} \mathrm{NTA}$, the ${ }^{1} \mathrm{H}-\mathrm{NMR}$ spectrum of the acid dissolved in DMSO was measured. The spectrum shows the following signals: a singlet signal at $\delta$ 3.55-3.79 p.p.m, for the six protons of the three-methylene groups, a broad singlet signal at $\delta 11.20$ 11.45 p.p.m with integration values $(14.529 / 7.5)=1.93: 6.11 \sim 2$ : 6, i.e. two carboxylic, and six methylene protons.

The results of elemental analysis for the studied 1:1 acid complexes, together with some of their physicochemical properties along with the proposed formulae are shown in Table (1).

Table 1

Analytical and Physical Data of (1:1) Acid Metal (II) Complexes of NTA.

\begin{tabular}{|c|c|c|c|c|c|c|c|c|c|c|c|}
\hline \multirow{2}{*}{$\begin{array}{c}\text { Complex } \\
1: 1 \\
\end{array}$} & \multirow{2}{*}{ M.Wt. } & \multirow{2}{*}{$\begin{array}{c}\text { Solubility } \\
\mathrm{g} / \mathrm{L}\end{array}$} & \multirow{2}{*}{ Color } & \multicolumn{2}{|c|}{$\left[\right.$ Metal] ${ }^{\mathrm{II}} \%$} & \multicolumn{2}{|c|}{$\mathrm{C} \%$} & \multicolumn{2}{|c|}{$\mathrm{N} \%$} & \multicolumn{2}{|c|}{$\mathrm{H} \%$} \\
\hline & & & & Calc. & Found & Calc. & Found & Calc. & Found & Calc. & Found \\
\hline $\mathrm{H}[\mathrm{CuNTA}]$ & 252.55 & 8.33 & blue & 25.15 & 25.97 & 28.52 & 27.82 & 5.55 & 5.69 & 2.37 & 2.93 \\
\hline $\mathrm{H}[\mathrm{NiNTA}]$ & 247.69 & 4.71 & $\begin{array}{l}\text { greenish } \\
\text { blue }\end{array}$ & 23.51 & 23.02 & 29.06 & 28.89 & 5.72 & 5.48 & 2.83 & 2.13 \\
\hline $\mathrm{H}[\mathrm{CoNTA}]$ & 247.93 & 3.86 & $\begin{array}{l}\text { pinkish } \\
\text { violet }\end{array}$ & 23.79 & 24.14 & 29.03 & 28.48 & 5.64 & 5.51 & 2.82 & 2.51 \\
\hline $\mathrm{H}[\mathrm{CaNTA}]$ & 229.08 & 12.07 & white & 17.47 & 17.60 & 31.44 & 30.96 & 6.11 & 6.06 & 3.05 & 3.43 \\
\hline $\mathrm{H}[\mathrm{ZnNTA}]$ & 254.37 & 2.67 & white & 25.78 & 26.00 & 25.52 & 23.73 & 5.50 & 5.11 & 2.75 & 2.73 \\
\hline $\mathrm{H}[\mathrm{MnNTA}]$ & 243.94 & 2.74 & faint rose & 22.54 & 23.00 & 29.50 & 29.32 & 5.74 & 5.26 & 2.87 & 2.80 \\
\hline $\mathrm{H}[\mathrm{CdNTA}]$ & 301.41 & 5.47 & white & 37.29 & 36.82 & 23.88 & 23.23 & 4.64 & 4.41 & 2.32 & 2.47 \\
\hline $\mathrm{H}[\mathrm{SrNTA}]$ & 276.62 & 10.73 & white & 31.67 & 30.95 & 26.02 & 25.97 & 5.06 & 4.63 & 2.53 & 2.39 \\
\hline $\mathrm{H}[\mathrm{BaNTA}]$ & 326.34 & 18.03 & white & 42.08 & 41.56 & 22.06 & 22.30 & 4.29 & 4.28 & 2.15 & 2.18 \\
\hline
\end{tabular}




\begin{tabular}{|c|c|c|c|c|c|c|c|c|c|c|c|}
\hline \multirow{2}{*}{$\begin{array}{c}\text { Complex } \\
1: 1\end{array}$} & \multirow{2}{*}{ M.Wt. } & \multirow{2}{*}{$\begin{array}{c}\text { Solubility } \\
\text { g/L }\end{array}$} & \multirow{2}{*}{ Color } & \multicolumn{2}{|c|}{$[\text { Metal] }]^{\text {II } \%}$} & \multicolumn{2}{|c|}{$\mathrm{C} \%$} & \multicolumn{2}{|c|}{ N\% } & \multicolumn{2}{|c|}{$\mathrm{H} \%$} \\
\hline & & & & Calc. & Found & Calc. & Found & Calc. & Found & Calc. & Found \\
\hline $\mathrm{H}[\mathrm{MgNTA}]$ & 213.21 & 10.88 & white & 11.36 & 10.97 & 28.76 & 28.54 & 5.64 & 5.05 & 4.40 & 4.57 \\
\hline $\mathrm{H}[\mathrm{PbNTA}]$ & 396.19 & 3.77 & white & 52.29 & 51.99 & 18.17 & 18.28 & 3.53 & 3.52 & 1.77 & 1.74 \\
\hline
\end{tabular}

The only papers that dealt with the IR spectra of solid acid divalent metal complexes of NTA give the formulae for $\mathrm{Mg}, \mathrm{Ca}, \mathrm{Sr}$ and $\mathrm{Ba}$ complexes as $\left(\mathrm{H}[\mathrm{Mg}(\mathrm{NTA})] \cdot 3 \mathrm{H}_{2} \mathrm{O}, \mathrm{H}[\mathrm{Ca}(\mathrm{NTA})] \cdot 2 \mathrm{H}_{2} \mathrm{O}\right.$, $\mathrm{H}[\mathrm{Sr}(\mathrm{NTA})] \cdot 4 \mathrm{H}_{2} \mathrm{O}$ and $\mathrm{H}[\mathrm{Ba}(\mathrm{NTA})] \cdot 3 \mathrm{H}_{2} \mathrm{O}$ respectively) [6,12]. In their preparation technique, Tomita and Uneno [6] recrystallised the solid acid complexes from water. Furthermore, they did not oven-dry the products. The metal, carbon, hydrogen and nitrogen contents of all the eleven complexes described in the present study suggests that they are all anhydrous, thus having the unified formula $\mathrm{H}\left[\mathrm{M}^{\mathrm{II}}(\mathrm{NTA})\right]$. Their molecular weights were calculated on this basis.

Since the structure of $\mathrm{H}_{3}$ NTA does not allow the formation of square planar complexes, then the 1:1 complexes of the present study should have the tetrahedral alternative. This is confirmed by calculating the magnetic moments of the complexes of the paramagnetic metal ions. The values in B.M. are as follows: $\mathrm{H}[\mathrm{Cu}(\mathrm{NTA})]=1.83, \mathrm{H}[\mathrm{Ni}(\mathrm{NTA})]=3.17, \mathrm{H}[\mathrm{Co}(\mathrm{NTA})]=4.30$ and $\mathrm{H}[\mathrm{Mn}(\mathrm{NTA})]$ $=5.81$. It is well known that tetrahedral $\mathrm{Co}$ (II) complexes have magnetic moments ranging from 4.404.88 B.M. while octahedral Co(II) complexes have values around 5.1 B.M [13, 14]. This tetrahedral structure is supported by the IR spectra, (Table 2), of the solid complexes where all these spectra contained the $v_{(\mathrm{COOM})}\left(\mathrm{str}\right.$.) band at around $1600 \mathrm{~cm}^{-1}$.

Table 2 also shows an interesting observation where the $v_{\mathrm{OH}}$ (str.) for group A metal complexes ranges from $3375-3458 \mathrm{~cm}^{-1}$ while that for group B metal complexes ranges from $3502-3628 \mathrm{~cm}^{-1}$. This may be explained in the light of the $\mathrm{M}-\mathrm{O}$ bond strength which is expected to be stronger in group A complexes with smaller ionic radii than in group B metal complexes with larger ionic radii. This is at once reflected on the $\mathrm{O}-\mathrm{H}$ bond strength being weaker in-group complexes.

Table 2

Tentative vibration bands assignments $\left(\mathrm{cm}^{-1}\right)$ of the metal complexes (1:1)

\begin{tabular}{|lcccccc|}
\hline \multicolumn{1}{|c}{ Complex } & $-\mathrm{COOH}$ & $\left(\mathrm{v}_{1}\right)-\mathrm{COOM}$ & $\mathrm{O}-\mathrm{H}$ & $\mathrm{N}-\mathrm{H}$ & $\left(\mathrm{v}_{4}\right) \mathrm{M}-\mathrm{O}$ & $\mathrm{M}-\mathrm{N}$ \\
\hline $\mathrm{H}[\mathrm{Cu}(\mathrm{NTA})]$ & $1733(\mathrm{~s})$ & 1660 & $3458(\mathrm{w})$ & $2992(\mathrm{mw})$ & $368(\mathrm{~m})$ & $560(\mathrm{w})$ \\
$\mathrm{H}[\mathrm{Co}(\mathrm{NTA})]$ & $1732(\mathrm{~s})$ & 1677 & $3430(\mathrm{~ms})$ & $2952(\mathrm{mw})$ & $407(\mathrm{w})$ & $544(\mathrm{~m})$ \\
$\mathrm{H}[\mathrm{Ni}(\mathrm{NTA})]$ & $1730(\mathrm{~s})$ & 1675 & $3424(\mathrm{~s})$ & $2910(\mathrm{w})$ & $402(\mathrm{~m})$ & $549(\mathrm{~ms})$ \\
$\mathrm{H}[\mathrm{Mg}(\mathrm{NTA})]$ & $1735(\mathrm{~s})$ & 1675 & $3401.5(\mathrm{~s})$ & $2993(\mathrm{~s})$ & $403(\mathrm{~s})$ & $561(\mathrm{~s})$ \\
$\mathrm{H}[\mathrm{Zn}(\mathrm{NTA})]$ & $1730(\mathrm{~m})$ & 1630 & $3375(\mathrm{~s})$ & $2940(\mathrm{w})$ & $420(\mathrm{w})$ & $544(\mathrm{~m})$
\end{tabular}




\begin{tabular}{|lcccccc|}
$\mathrm{H}[\mathrm{Mn}(\mathrm{NTA})]$ & $1733(\mathrm{w})$ & 1680 & $3502(\mathrm{~m})$ & $2989(\mathrm{~m})$ & $417(\mathrm{~m})$ & $534(\mathrm{~m})$ \\
$\mathrm{H}[\mathrm{Cd}(\mathrm{NTA})]$ & $1730(\mathrm{vw})$ & 1640 & $3513(\mathrm{~m})$ & $2930(\mathrm{w})$ & $412(\mathrm{~m})$ & $536(\mathrm{~ms})$ \\
$\mathrm{H}[\mathrm{Ca}(\mathrm{NTA})]$ & $1736(\mathrm{vw})$ & 1666 & $3628(\mathrm{w})$ & $2998(\mathrm{~m})$ & $378(\mathrm{vw})$ & $539,598(\mathrm{w})$ \\
$\mathrm{H}[\mathrm{Sr}(\mathrm{NTA})]$ & $1729(\mathrm{vw})$ & 1665 & $3529(\mathrm{~s})$ & $2998(\mathrm{~m})$ & $380(\mathrm{~m})$ & $532,550(\mathrm{~s})$ \\
$\mathrm{H}[\mathrm{Ba}(\mathrm{NTA})]$ & $1726(\mathrm{w})$ & 1670 & $3528(\mathrm{~m})$ & $2969(\mathrm{w})$ & $375(\mathrm{M})$ & $509,532(\mathrm{~s})$ \\
\hline $\mathrm{H}[\mathrm{Pb}(\mathrm{NTA})]$ & $1728(\mathrm{vw})$ & 1655 & $3508.5(\mathrm{~m})$ & $2989(\mathrm{~s})$ & $393(\mathrm{w})$ & $515,546(\mathrm{~m})$ \\
\hline
\end{tabular}

The assignment of the M-N and M-O stretching frequencies (Table 2) is supported by the work of Condrate and Nakamoto [11] who located the M-N stretching frequencies for some divalent metal glycine complexes in the range 550-450 $\mathrm{cm}^{-1}$ and M-O stretching bands between 420 and $280 \mathrm{~cm}^{-1}$.

The two principal bands assigned as $v_{\mathrm{C}=\mathrm{O}}$ stretching $\left(v_{1}\right)$ and $v_{\mathrm{M}-\mathrm{O}}\left(v_{4}\right)$ are metal sensitive, since these bands shifts progressively to higher frequencies as the ionic radius of the metals change. This is exhibited by the linear relationship between $v_{1}$ and $v_{4}$ as illustrated in Fig. (1).

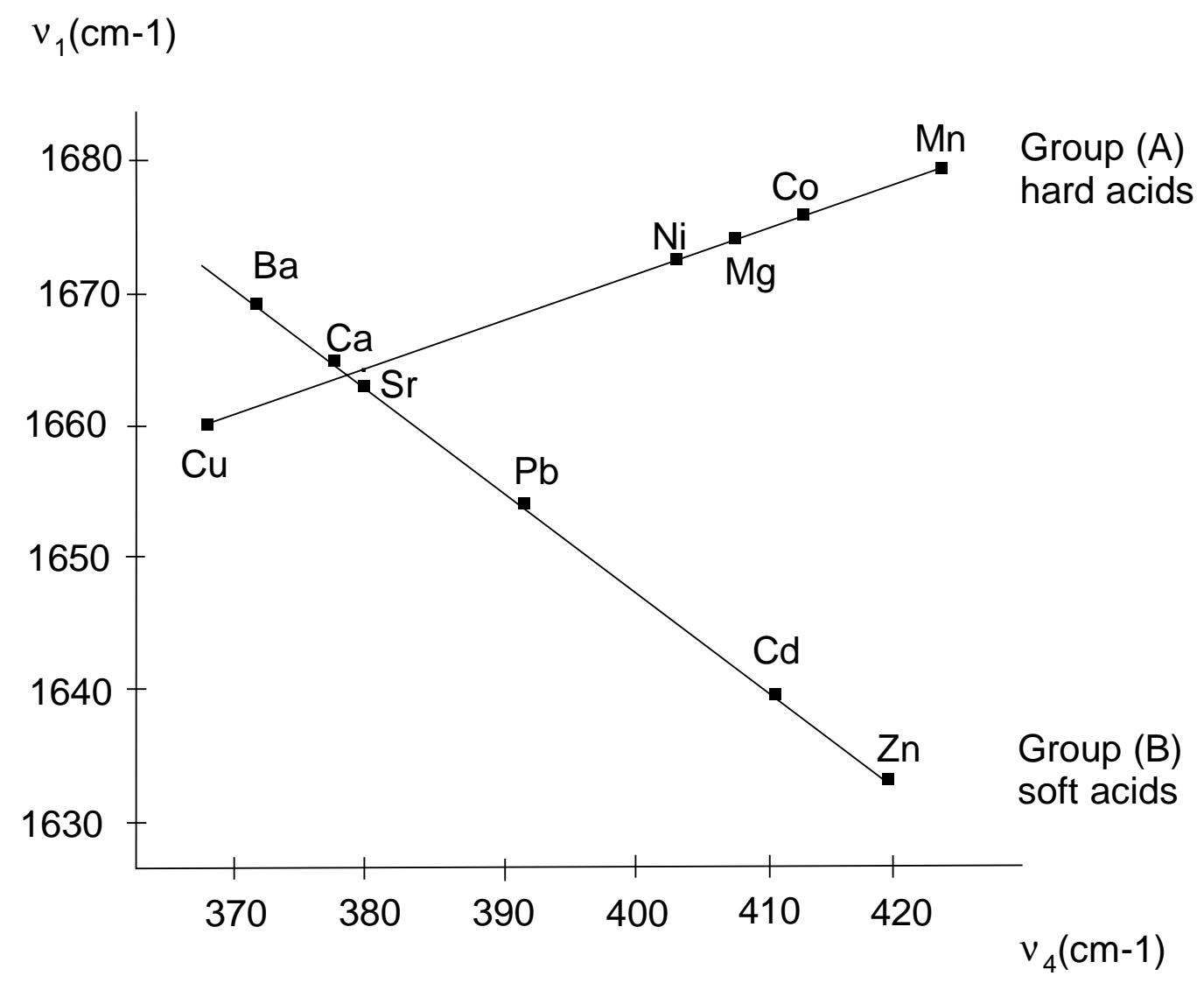

(Fig. 1) $v_{4}-v_{1}$ relationships for the studied complexes 
Before discussing the UV-visible spectra of the colored complexes of divalent $\mathrm{Cu}, \mathrm{Ni} \& \mathrm{Co}$ it should be noted that upon dissolution in water the tetrahedral complexes add two water molecules in cis- position to give an octahedral structure [4].

The UV-visible spectrum of the $\mathrm{Cu}$ (II) complex showed a broad band with $\lambda_{\max }$ at $784 \mathrm{~nm}(1.27 \mathrm{x}$ $10^{4} \mathrm{~cm}^{-1}$ ) which is assigned to ${ }^{2} \mathrm{E} \rightarrow^{2} \mathrm{~T} 2$ transition. $10 \mathrm{Dq}$ equals $12700 \mathrm{~cm}^{-1}$. This value is very close to that calculated by Dreisch for the aqueous $\mathrm{Cu}$ (II) [15], which is equal to $12200 \mathrm{~cm}^{-1}$.

The UV-visible spectrum of the Ni(II) complex showed two bands: one at $384 \mathrm{~nm}\left(26042 \mathrm{~cm}^{-1}\right)$ for the ${ }^{3} \mathrm{~A}_{2 \mathrm{~g}} \rightarrow{ }^{3} \mathrm{~T}_{1 \mathrm{~g}} \quad$ (F) transition and another band at $609 \mathrm{~nm}\left(16420 \mathrm{~cm}^{-1}\right)$ for the ${ }^{3} \mathrm{~A}_{2 \mathrm{~g}} \rightarrow{ }^{3} \mathrm{~T}_{2 \mathrm{~g}}$ (F) transition, while that for the Co(II) complex showed a shoulder at $456 \mathrm{~nm}\left(21929.8 \mathrm{~cm}^{-}\right.$ ${ }^{1}$ ) for the ${ }^{4} \mathrm{~A} 1_{\mathrm{g}} \rightarrow{ }^{4} \mathrm{~A}_{2 \mathrm{~g}}(\mathrm{~F})$ transition and a band at $511 \mathrm{~nm}\left(19569.5 \mathrm{~cm}^{-1}\right)$ for the ${ }^{4} \mathrm{~T}_{1 \mathrm{~g}}(\mathrm{~F}) \rightarrow{ }^{4} \mathrm{~T}_{1 \mathrm{~g}}(\mathrm{P})$ transition. The $10 \mathrm{Dq}$ values for Ni(II) and Co(II) complexes were calculated using:

(a) The equations on the energy terms for the triplet state for $\mathrm{Ni}$ (II) and the quartet states for $\mathrm{Co}$ (II) [16].

(b) The Tanabe and Sugano diagrams for the $\mathrm{d}^{8}$ and $\mathrm{d}^{7}$ systems respectively.

Applying method (a) and knowing that $\mathrm{B}$ for $\mathrm{Ni}(\mathrm{II})=1080$ and for $\mathrm{Co}(\mathrm{II})=970$, the $10 \mathrm{Dq}$ values for the $\mathrm{Ni}$ (II) and $\mathrm{Co}$ (II) complexes were found to be $17394 \mathrm{~cm}^{-1}$ and $15500 \mathrm{~cm}^{-1}$ respectively. Applying method (b) the $10 \mathrm{Dq}$ values for the Ni(II) and Co(II) complexes were found to be 17312 $\mathrm{cm}^{-1}$ and $15520 \mathrm{~cm}^{-1}$.

The pKa values for the eleven acid complexes calculated from the results of titration of $0.01 \mathrm{molar}$ solution of $\mathrm{K}[\mathrm{M}(\mathrm{NTA})]$ with 0.1 molar solution of hydrochloric acid at $25^{\circ} \mathrm{C}$ according to the method of calculations described by Albert and Serjeant [8] are given in Table (3) together with the $\mathrm{pK}_{\mathrm{a}}$ values of the $\left[\mathrm{M}\left(\mathrm{H}_{2} \mathrm{O}\right)_{\mathrm{n}}\right]^{2+}$ ions [8], also with the $\log \beta_{1}$ values of the $[\mathrm{M}(\mathrm{NTA})]^{\mathrm{n}-}$ complexes.

Aqueous medium Aqueous medium / $\mathrm{HCl}$ $\mathrm{K}[\mathrm{M}(\mathrm{NTA})]$ $\mathrm{K}\left[\mathrm{M}(\mathrm{NTA}) \cdot\left(\mathrm{H}_{2} \mathrm{O}\right)_{2}\right]$ $\left[\mathrm{M}(\mathrm{HNTA}) \cdot\left(\mathrm{H}_{2} \mathrm{O}\right)_{3}\right]+$ $\mathrm{KCl}$

The expected proportionality between the two series of $\mathrm{pK}_{\mathrm{a}}$ values is clear where the $\mathrm{pK}_{\mathrm{a}}$ value of any $\left[\mathrm{M}(\mathrm{HNTA}) .\left(\mathrm{H}_{2} \mathrm{O}\right)_{3}\right]$ is derived from that of the free $\left[\mathrm{M}\left(\mathrm{H}_{2} \mathrm{O}\right)_{\mathrm{n}}\right]^{2+}$ ion and that of $\mathrm{H}_{3} \mathrm{NTA}$. The relation between $\mathrm{pK}_{\mathrm{a}}$ of $\left[\mathrm{M}(\mathrm{HNTA}) .\left(\mathrm{H}_{2} \mathrm{O}\right)_{3}\right]$ and $\log \beta_{1}$ of the corresponding [M(NTA). $\left.\left(\mathrm{H}_{2} \mathrm{O}\right)_{2}\right]^{-}$ complex may be explained according to the fact that the more stable the complex the higher the dissociation of the corresponding acid complex.

X-ray patterns of the prepared solid NTA complexes were taken over the range of $2 \theta \theta=6-60^{\circ}$. The principal " $\mathrm{d}$ " lines and its intensity are represented in Table 4. All complexes are crystalline solids, where $\mathrm{Mg}, \mathrm{Ca}$ and $\mathrm{Sr}$ complexes have a similar structure (isostructural). The $\mathrm{Ni}, \mathrm{Cu}$ and $\mathrm{Cd}$ display a different structure and a very high degree of crystallinity while Co and $\mathrm{Zn}$ complexes are characterized by a low degree of crystallinity, but the strongest lines in the radiograms assume almost the same position as in the radiograms of other complexes. Low symmetry, large size of unit cells and various degrees of crystallinity are characteristics of all crystalline complexes. 
Table 3

Comparison between pKa values of acid metal complexes and pKa of divalent metal ions

\begin{tabular}{|c|c|c|c|}
\hline $\begin{array}{l}\text { Divalent metal } \\
\text { ions }\left[\mathrm{M}^{2+}\right]\end{array}$ & $\begin{array}{l}\mathrm{pK}_{\mathrm{a}} \text { of aquo-divalent metal } \\
\text { ions }\left[\mathrm{M}\left(\mathrm{H}_{2} \mathrm{O}\right)_{\mathrm{n}}\right]^{2+}[8]\end{array}$ & $\begin{array}{c}\mathrm{pK}_{\mathrm{a}} \text { of the }(1: 1) \text { acid complex } \\
\left.[\mathrm{M}(\mathrm{HNTA})] \cdot\left(\mathrm{H}_{2} \mathrm{O}\right)_{3}\right] \\
\text { (this work) }\end{array}$ & $\begin{array}{c}\log \beta_{1} \text { of the } \\
{[\mathrm{M}(\mathrm{NTA})]^{\mathrm{n}-} \text { complex }} \\
{[17]}\end{array}$ \\
\hline Copper & $6.5-7.9$ & 1.46 & $10.05 \pm 0.01$ \\
\hline Nickel & 9.84 & 2.21 & $11.54+0.08$ \\
\hline Cobalt & 9.85 & 2.44 & $10.81 \pm 0.03$ \\
\hline Manganese & 10.59 & 4.22 & $7.36 \pm 0.05$ \\
\hline Calcium & 12.90 & 4.76 & $6.46+0.01$ \\
\hline Cadmium & 9.10 & 2.82 & $9.20+0.2$ \\
\hline Zinc & 8.96 & 1.85 & $10.44 \pm 0.05$ \\
\hline Barium & 13.36 & 5.22 & $4.83 \pm 0.03$ \\
\hline Strontium & 13.20 & 5.75 & $5.01 \pm 0.01$ \\
\hline Lead & 8.00 & 1.68 & $11.47 \pm 0.04$ \\
\hline Magnesium & 11.42 & 5.86 & $5.46+0.02$ \\
\hline
\end{tabular}

Table 4.

X-ray diffraction patterns of $\mathrm{H}[\mathrm{M}(\mathrm{NTA})] 1: 1$ complexes, $\left\{\mathrm{d}\left(10^{-1} \mathrm{~nm}\right)_{\text {Intensity } \%}\right\}$

\begin{tabular}{|c|c|c|c|c|}
\hline HNTA & $\mathrm{H}[\mathrm{Mg}(\mathrm{NTA})]$ & $\mathrm{H}[\mathrm{Ca}(\mathrm{NTA})]$ & $\mathrm{H}[\mathrm{Sr}(\mathrm{NTA})]$ & $\mathrm{H}[\mathrm{Cd}(\mathrm{NTA})]$ \\
\hline 4.55100 & $7.85_{85}$ & $10.27_{65}$ & $10.26_{100}$ & $7.91_{40}$ \\
\hline $4.44_{100}$ & $4.92_{25}$ & $5.14_{25}$ & $9.80_{100}$ & $5.57_{40}$ \\
\hline $3.14_{95}$ & 4.52100 & $5.04_{50}$ & $4.99_{40}$ & $4.48_{35}$ \\
\hline $3.01_{65}$ & $3.17_{50}$ & $3.44_{100}$ & $4.83_{100}$ & $3.70_{85}$ \\
\hline $2.45_{55}$ & $2.57_{45}$ & $2.44_{70}$ & $3.20_{100}$ & $3.02_{100}$ \\
\hline $\mathrm{H}[\mathrm{Co}(\mathrm{NTA})]$ & $\mathrm{H}[\mathrm{Ni}(\mathrm{NTA})]$ & $\mathrm{H}[\mathrm{Cu}(\mathrm{NTA})]$ & $\mathrm{H}[\mathrm{Zn}(\mathrm{NTA})]$ & \\
\hline $13.30_{100}$ & $8.30_{100}$ & $9.25_{100}$ & 7.9760 & \\
\hline $7.99_{25}$ & $6.67_{60}$ & $6.96_{80}$ & $6.68_{75}$ & \\
\hline $6.73_{40}$ & $5.30_{100}$ & $5.24_{90}$ & $5.30_{60}$ & \\
\hline $5.63_{50}$ & $5.07_{70}$ & $5.19_{95}$ & $5.04_{100}$ & \\
\hline $4.09_{30}$ & $4.93_{70}$ & $4.19_{100}$ & $3.18_{25}$ & \\
\hline
\end{tabular}




\section{Experimental}

\section{General}

All chemicals used in the present study were reagent grade. The metal content in all the studied complexes was determined by atomic absorption using a Perkin-Elmer A.A.S. 3100 spectrophotometer. Carbon, hydrogen and nitrogen were determined at the microanalytical laboratory, Ain Shams University using a Perkin-Elmer 2400 C. H. N. Elemental Analyzer. IR spectra of the solid complexes were recorded on a Perkin-Elmer spectrophotometer model Jasco FT-IR-300 E Fourier Transform Infrared using $\mathrm{KBr}$ discs (400-4000 $\left.\mathrm{cm}^{-1}\right)$ and CsI technique (200-400 $\left.\mathrm{cm}^{-1}\right)$ at room temperature $\left(25^{\circ} \mathrm{C}\right)$. The solubility of the prepared complexes was determined by shaking few milligrams of the complex with distilled water in an air thermostat at $25 \pm 0.2{ }^{\circ} \mathrm{C}$ for four hours. The suspension rapidly filtered and a given volume of the filtrate was titrated potentiometrically against a standard sodium hydroxide solution using Fisher Accument model $950 \mathrm{pH}$ meter. The solubility was expressed in grams/liter. UV/Visible spectra of the colored complexes of $\mathrm{Cu}, \mathrm{Ni}$ and $\mathrm{Co}$ dissolved in water were recorded on a UV-visible spectrophotometer model № $\mathrm{CO} 180$, 437, lambda $3 \mathrm{~B}$ using a 1 $\mathrm{cm}$ quartz cell in the range $200-900 \mathrm{~nm}$ at room temperature. Magnetic susceptibilities of the paramagnetic metal complexes of $\mathrm{Cu}, \mathrm{Ni}, \mathrm{Co}$ and $\mathrm{Mn}$ were measured by the Guoy's method at room temperature $\left(25 \pm 0.2{ }^{\circ} \mathrm{C}\right)$ using a magnetic susceptibility balance Johnson Matthy, Alfa products, Model No. MKI Diamagnetic corrections were calculated from Pascal's constants. Mercury tetrakisthiocyanatocobaltate was used as a standard. The $\mathrm{pK}_{\mathrm{a}}$ values of the acid complexes were determined by titrating the potassium salt; K[M(NTA)], against standard hydrochloric acid as described by Albert and Serjeant [8].

\section{Preparation of the acid nitrilotriacetates complexes, [HMNTA]}

The calculated amounts of the metal carbonates of $\mathrm{Mn}, \mathrm{Cd}, \mathrm{Ca}, \mathrm{Sr}, \mathrm{Ba}$ and $\mathrm{Pb}$ or the basic carbonate of $\mathrm{Cu}, \mathrm{Ni}, \mathrm{Co}, \mathrm{Zn}$ and $\mathrm{Mg}$ were added to the aqueous suspension of the equivalent amount of nitrilotriacetic acid in water to give 0.10 molar solution. The mixture was heated gently nearly to boiling for about one hour. After complete reaction, the reaction mixture was concentrated by heating, then $96 \%$ ethanol was added and the reaction mixture cooled under tap water or in an ice bath. A dense crystalline precipitate was obtained, filtered, washed with $96 \%$ ethanol, dried at $105{ }^{\circ} \mathrm{C}$ in an oven, then placed in a vacuum dessiccator, over $\mathrm{CaCl}_{2}$. The same procedure was followed for the preparation of $\mathrm{H}_{2} \mathrm{KNTA}$ and $\mathrm{K}_{3}$ NTA where smaller volumes of water and larger volumes of $96 \%$ ethanol were used.

The potassium salts of the acid nitrilotriacetates were prepared by the following reaction:

$$
2 \mathrm{H}_{3}[\mathrm{NTA}]+2 \mathrm{MCO}_{3}+\mathrm{K}_{2} \mathrm{CO}_{3} \stackrel{\text { heat }}{\longrightarrow} 2 \mathrm{~K}[\mathrm{M}(\mathrm{NTA})]+3 \mathrm{CO}_{2}+3 \mathrm{H}_{2} \mathrm{O}
$$


After cooling, the solution was transferred quantitatively to a volumetric flask, then made up to the mark with distilled water. Suitable aliquots of these solutions were titrated potentiometrically against standard hydrochloric acid solution. No more than 0.06 in a $\mathrm{pK}_{\mathrm{a}}$ value scatter was allowed for a set of readings in any given estimation.

X-ray diffraction patterns (XRD) of the prepared solid complexes were recorded using a Philips Xray diffractometer model PW 1140/90 and Fe-filtered CoK radiation. The X-ray patterns of powdered samples were recorded automatically with a scanning speed of $2^{\circ}$ per minute, and the scanning angular range $(2 \theta)$ was from $6^{\circ}-60^{\circ}$. All the diffraction patterns were measured at room temperature. The "d" $\left(10^{-1} \mathrm{~nm}\right)$-spacing was calculated and compared with data on they're relative intensities given in the ASTM cards.

\section{References and Notes}

1. L. O. S. Li, and J. Huang, Water Science and Technology, 1993, 191, 28.

2. K. Prochazka, V. Lopala, J. Tolman, J. Novak and P. Reznicek. Czech. C.S. 1977, 695, 196.

3. M. Yotsuya, K. Mae, S. Jinnouchi and T. Ochiai. Jpn. Kokai Tokkyo Appl., 1978, 78/20, 1636.

4. D. L. Rabenstein and R. J. Kula, J. Am. Chem. Soc., 1969, 91, 2492

5. M. James. Can J. Chem., 1974, 52, 4106.

6. Y. Tomita and K. Uneno. Bull. Chem. Soc. Jap. 1963, 36, 1069.

7. G. Beck. Helv. Chim. Acta, 1946, 29, 357.

8. A. Albert and E.P. Serjeant. The determination of ionization constants, Chapman and Hall, London, 1984.

9. A.W. Herlinger, S.L. Wenhold and T.T. Long, J. Am.Chem. Soc. 1970, 92, 6474.

10. K. Nakamoto. Infrared and Raman spectra of Inorganic and Coordination Compounds, John Wily \& Sons, New York, 1978.

11. H. A. Tajmir-Riah, Spectrochim. Acta, 1982, 38A, 10.

12. D. A. Chen, R. J. Motekaitis and A. E. Martell, Can J. Chem. 1993, 71, 1524.

13. A.Cotton and G. Wilkinson. Advanced Inorganic Chemistry, John Wily \& Sons, NewYork, 1972.

14. N. N. Greenwood and A. Earnshaw, Chemistry of the Elements, Pergamon Press, U.K., 1985.

15. Y. Tanabe and S. Sugano, J. Phys. Soc. Jap., 1954, 9, 772.

16. S. F. A. Kettle. Coordination Chemistry, Thomas Nelson \& Sons, UK, 1975.

17. G. Anderegg. Critical survey of stability constants of NTA complexes: pure and applied chemistry 1982, 54, 2693.

Sample Availability: Samples are available from the authors

(C) 2000 by MDPI (http://www.mdpi.org). Reproduction is permitted for noncommercial purposes. 